Шевців Галина,

кандидат філологічних наук, старший викладач, Дрогобицький державний педагогічний університет імені Івана Франка

\title{
ДО ПИТАННЯ ДОСЛІДЖЕННЯ ЖАНРУ ХУДОЖНЬОЇ АВТОБІОГРАФІЇ В НІМЕЦЬКОМУ ЛІТЕРАТУРОЗНАВСТВІ
}

Статтю присвячено питанню вивчення жанру художньої автобіографії в німечькому літературознавстві XX-го століття. Проаналізовано окремі наукові розвідки німецьких дослідників проблем літературної автобіографії. Виділено актуальні проблеми та основні тенденції німецьких досліджень літературної автобіографії вказаного періоду. Підкреслено часте звернення німецьких літературознавиів XX-го століття до „Поезї $i$ правди” Й.-В. Гете як важливого ілюстративного матеріалу базових жанрових теоретичних позииій.

Ключові слова: автобіограф, автобіографія, автор, жанр, індивідуальність, самозображення, спогад.

Shevtsiv $H$. In reference to fiction autobiography genre in the German studies in the German study of Literature.

The article is devoted to the studying of the literary autobiography genre specification question in the German literary studies of the XX century. Separate literary autobiography scientific researches problems of the German scholars are analyzed in the article. In the center of the stated period, there is the autobiography narration truthfulness question and memory role when being created, autobiography genre separation from the other genres, autobiography creation motivation and the narrative perspective change, the women autobiography peculiarities. The $W$. Dilthey philosophy literary autobiography treatment is analyzed.

Key words: autobiography, author, genre, individuality, self-depiction, memory.

Художня автобіографія має тривалу історію свого жанрового становлення, відповідно, широку дослідницьку базу вивчення його теоретичних аспектів, зокрема в українському літературознавстві (О. Галич, І. Акіншина, О. Дацюк, Г. Грегуль, Л. Мороз, О. Петрусь, Т. Черкашина). У контексті наших студій «Поезії і правди» Й.-В. Гете неодноразово виникала необхідність звернення до розгляду теоретичних засад жанру літературної автобіографії німецьких літературознавців XX-го століття, які називають цей життєпис кульмінацією (Г. Нігл, К. Д. Мюллер, В. Нойманн) та парадигмою європейського спогадового письма (О. Нітгаммер), життєвим підсумком незадоволеної, але свідомої своїх помилок людини (К.-Д. Мюллер). У нашій розвідці ми ставимо за мету узагальнити та підсумувати матеріал окремих німецькомовних джерел 3 
проблематики жанру художньої автобіографії, який доступний читачеві лише мовою оригіналу.

Актуальність статті визначається необхідністю розробки чітких жанрових критеріїв художньої автобіографії, до якої активно долучилися представники німецької літературознавчої науки.

Об’єктом дослідження у пропонованій статті є проблема літературної автобіографії у художній творчості.

Предметом дослідження $€$ вивчення основних тенденцій німецьких теоретичних розвідок ХХ-го століття у галузі художньої автобіографії.

Проблема дослідження художньої автобіографії в німецькому літературознавстві $\epsilon$ актуальною 3 огляду на різноманіття та важливість иї теоретичних аспектів. Фундаментальною роботою 3 теорії автобіографічного жанру в німецькому літературознавчому просторі визнано дослідження Г. Міша «Історія автобіографії» [1], яке вийшло друком у 1949-69 роках, і науковою основою якого є історична модель Гете з його «Поезії і правди». Розглядаючи історію художньої автобіографії як історію людського самоусвідомлення та акцентуючи виняткове значення цього жанру для глибокого аналізу внутрішнього стану людини, дослідник аналізує досвід життєпису та саморозуміння видатних діячів і мислителів різних епох європейської історії. При цьому Г. Міш розглядає визначені ним усі можливі форми людського самовираження (молитву, звіт, симульовану судову промову, риторичну декламацію, наукову чи художню характеристику, промову, літературний портрет, сімейну хроніку, мемуари, чисто предметну прагматичну розповідь, роман й біографію в їі найрізноманітніших формах, епос й драму).

Гуманітарні традиції Г. Міша розвивали Т. Кляйбер, Г. Глягау, В. Маргольц та інші німецькі дослідники спогадового письма. У XX столітті появляється ряд теоретичних робіт, які актуальні й по сьогоднішній день. Серед них дослідження М. Шюц «Автобіографія як твір мистецтва» (1963), Р.-Р. Вутенова «Згадане Я» (1974), М. Зальцманн «Комунікативна структура 
автобіографії» (1988), І. Айхінгер «Проблеми автобіографії як мовного твору мистецва» (1989) та інші.

Робота I. Айхінгер присвячена теоретичним питанням автобіографічного жанру та передумов поділу текстів на прагматичні та власне художні, а також питанням розмежування автобіографії та інших літературних жанрів. Дослідниця визначає автобіографічне зображення як окремий спосіб самовираження, відмінний від щоденникових записів, мемуарних спогадів та епістолярного літературного жанру. Вирішальну роль при встановленні цієї відмінності відіграють специфічна закритість зображення власного „Я” та строга перспектива розповіді на своє „Я” [2, с. 180].

У полі зору німецьких дослідників постає питання правдивості автобіографічної розповіді. Огляд наукових розвідок з проблем літератури факту демонструє неодноразове звернення їх авторів до «Поезії і правди» Гете. Варте уваги висвітлення Б. Нойманном культу Гете в німецькій автобіографії, який виходить 3 положення про взаємозалежність суспільного розвитку та автобіографічної форми викладу матеріалу, шукаючи посередництво між типологією характерів та типологією автобіографії [3, с. 295]. Важливу роль в розвитку німецької теорії художньої автобіографії відіграла робота «Літературна антропологія. Автобіографія та іï історія» Г. Пфотенгауера, в якій ознаки самотематизації розвиваються, насамперед, на основі психологічних та медичних діагнозів [4]. Суттєвим моментом при розгляді німецького автобіографізму є питання існування жіночих автобіографічних творів, яким 3 кінця 1970 року приділяється особлива увага. Проблемам жіночої автобіографії присвячують свої роботи Е. Рамм, М. Гольденрід, С. Бовеншен, О. Нітгаммер. Пояснюючи відсутність жіночих класичних автобіографій в німецькій літературі, Е. Рамм наголошує, що жінки взагалі переважно пишуть анонімно чи під псевдонімами. I не хочуть, або не можуть представити на суд читача своє життя під власним іменем [5, с. 137].

Епохою автобіографії називає XVIII століття К. Кляйн. У цей час інтроспективні автобіографічні твори, що базуються на самоспостереженні 
авторів, стають неабияк популярні. Такі твори сприяли глибокому самоаналізу та ідеї утвердження особистості. При цьому більша увага приділяється хронологічній послідовності зображуваних подій, які підведені під три обов'язкові етапи: дитинство та юність, навчання та розвиток особистості, початок творчої фази. Актуалізується питання, чи правду автобіографічного твору слід розглядати як знайдену в результаті глибокого самоаналізу, чи як майстерно вигадану в результаті бажання представити себе в бажаному світлі. Ще Аристотель провів чітку межу між істориком, який пише про те, що було насправді та літератором, який може писати й про те, що могло б статися. Автобіографія завжди знаходиться на межі між історіографією та літературою. До того ж автобіографія завжди залежна від сучасних їй філософських та суспільних теорій. Автобіографічний твір певного історичного періоду $\epsilon$ дзеркальним відображенням тогочасної концепції індивідуальності [6, с. 178].

Зображення прожитого пов’язане з певною долею художнього вимислу і немає єдиного критерію, який би чітко розмежовував правду та вимисел в автобіографічному творі. Реальні описи життя 3 дріб'язковими проблемами мають невеликі шанси завоювати інтерес читача, для якого замало хаотичного зображення подій, читач прагне отримати впорядкований опис життя. Визначаючи статус біографії як окремого жанру, К. Кляйн зауважує, що з боку літературознавства автобіографії була приділена більша увага, аніж біографії $[6$, c. 180$]$.

П.-А. Альт в роботі «Мода без методу? Роздуми про теорію науковолітературної біографії» дає економічне пояснення поширенню спогадових жанрів, оскільки література факту добре зарекомендувала себе на сучасному книжковому ринку [7, с. 23]. У літературознавстві все частіше йдеться про авторську концепцію твору, що демонструє схильність до опису певної моделі, a не конкретної особи. Авторство та твір виявляються гіпотетичними категоріями, замість яких використовується авторська концепція й текст. Цим проголошується повернення від вимислу закритої форми художнього тексту. Нову оцінку літературознавчих категорій частково можна пояснити 
поверненням до конструктивного мислення. Авторська модель вбирає в себе різні діахронічні та синхронічні плани, які позначають дивергентні авторські фігурації. Вони формально ділять текст та набирають великого значення при його аналізі. Авторська модель, наприклад, XVIII століття піддається іншим впливам, аніж сучасна авторська модель. До таких впливів дослідник зараховує поетологічні норми, ринкові тенденції, форми розповсюдження книжкового товару, знання, культурну ідентичність. Синхронічні змінні представлені в галузі текстуальних репрезентативних форм, до яких належать вибір літературного жанру, стиль, формальні традиції, зразки, відповідні часу стратегії письма [7, с. 27]. Розповідь в автобіографічному творі повинна бути позбавлена так званих білих плям, породжених проблемами пам'яті автобіографа чи відсутністю документальних даних. Автобіографія повинна розглядати свій предмет як мовні знаки та розшифровувати їх 3 герменевтичною точністю. Тоді можна сподіватися, що життя i твір не виявляться двома незалежними частинами, а навпаки, зійдуться у відношенні взаємозалежності.

Не втрачає актуальності робота німецького дослідника Ю. Кучинский „Проблеми автобіографіï” [8]. Простеження розвитку автобіографіï автор розпочинає 3 термінологічної проблеми, демонструє входження в німецьку мову слова „,автобіографія”. Погоджуючись, що між автобіографією та мемуарами важко провести чітку межу, автор запитує про існування такої межі взагалі. Не існує автобіографії, яка б не включала в себе спогади про інших людей, тобто мемуари. Проте не існує мемуарів без автобіографічних рис. Автобіографія вимагає від автора зосередження уваги на власній персоні, в мемуарах чи спогадах увага автора спрямовується на інших осіб. Автор дослідження зазначає, що для автобіографії характерне зображення дитинства та юнацьких років, що не є обов’язковим елементом мемуарів. Думки про себе можуть бути також оформленими у вигляді філософських роздумів про себе самого, у вигляді самоаналізу чи автопортрету. Ю. Кучинский називає 
автобіографію історичним зображенням свого „я” через його стосунки зі світом $[8$, c. 82$]$.

Ю. Кучинский підкреслює роль спогадів у написанні автобіографії. Навіть якщо автор використовує в роботі певні документи, щоденники, вони не переважать ролі пам'яті. Спогади носять суб'єктивний характер і тому можуть бути дуже різними: чіткими, ясними, неповними, неправильними. В автобіографію можуть бути включені й нечіткі спогади. Автор наголошує подвійну роль, яку можуть виконати спогади при написанні автобіографії. 3 одного боку, автобіографія без них $є$ немислима. 3 другого ж боку, неправильні, невизначені спогади можуть лише нашкодити при написанні автобіографії [8, с. 92]. Щоденники, листи, записки є суттєвою допомогою, проте вони не завжди наявні, коли людина через багато років береться за автобіографічний твір. Відомі випадки, коли такі особисті папери були власноруч знищені письменниками. Від автобіографа ми отримуємо таке зображення минулого, яке вимальовується в його свідомості. Тобто це картина минулого, яка виникає в його душі сьогодні. Більшість автобіографій зумовлені внутрішньою мотивацією, якийсь особливий зовнішній поштовх для їхнього написання є непотрібний.

Ще однією важливою проблемою, на думку Ю. Кучинский, є питання мотивації написання автобіографії. Цій проблемі присвячено окремий розділ книги під назвою «Чому пишуться автобіографіі?». У кожному окремому випадку до написання автобіографії спонукатимуть глибоко індивідуальні причини, які в більшості випадків для читача залишаться невідомими. Проблемою автобіографії $є$ дотримання необхідної дистанції, яка повинна існувати між автором та його власним „я”, а також між різним „я” минулого. Дистанція дасть можливість створити про себе правильні уявлення. Перш ніж говорити про дотримання такої дистанції, слід починати 3 iї створення. Дистанція між різними „я” минулого є подоланням дистанції, як наприклад, між „я” літнього автобіографа та його дитинством чи юністю. Автобіограф 
повинен однаково досконало володіти мистецтвом відчудження та його подолання.

Вартий уваги розгляд проблеми авторської ідентичності, започаткованої відомими французьким літературознавцем Ф. Леженом. Німецькою мовою їі можна сформулювати „Ich ist ein anderer”. Літературознавча суть цієї проблеми полягає у тому, що автобіографи мають тенденцію представляти себе інакшими, аніж вони є насправді. Здійснюватися це може як свідомо, так i підсвідомо. Ймовірно автобіограф взагалі не має інтересу до свого „я”, його цікавлять лише конкретні деталі. Тому частково описане ,я” буде іншим аніж „я” загалом. Така авторська позиція може привести до негативних наслідків при написанні автобіографії. Ю. Кучинский виділяє автобіографії, що носять характер дослідження власної душі та автобіографії, метою яких $\epsilon$ самоусвідомлення. Намір зробити власне „я” в найглибших виявленнях почуттів основною темою автобіографії викликає не тільки сумнів в істинності матеріалу, а й здоровий страх перед чванливістю, пихатістю, зарозумілістю автобіографа [8, с. 112]. Йдеться про те, що скромність людини не завжди дозволить таке глибоке занурення у іiі внутрішній світ. Якщо ж людина не достатньо скромна, то повинна бути витримана межа інтересу до так званого „,Внутрішнього світу” своєї особистості.

Автобіографії пишуться, як правило, від першої особи. Однак відомі автобіографії, де розповідь ведеться від третьої особи. А в деяких життєписах спостерігаємо перехід 3 однієї особи на іншу, як «Поезії і правді» Гете. Розповідь про себе від третьої особи надає твору підкресленої об'єктивності. Автор робить сам себе об’єктом дослідження. Оповідач в ролі третьої особи допомагає створити й дотримуватися необхідної для автобіографічного твору дистанції. Зміна оповідної перспективи в межах одного твору зумовлена причинами, які достеменно відомі лише автору. На основі аналізу К.-Д. Мюллером таких переходів [9, с. 221] можна лише припустити, що стоїть за зміною оповідної перспективи. 
Окремо звернемося до філософського трактування жанру художньої автобіографії як важливої передумови літературознавчих досліджень. Вивчення жанру автобіографії тісно пов’язане з іменем видатного німецького філософа та психолога В. Дільтая (1833-1911), ідеї якого безпосередньо вплинули на згадані вище концепції. Людське переживання, самоусвідомлення, можливості самопізнання та пізнання всього суспільства розглянуті ним 3 позиції „філософії життя”. Визначивши автобіографію як осмислення людиною власного життєвого шляху, що отримав літературну форму вираження, В. Дільтай застосовує для вивчення цього жанру герменевтичний підхід. Філософське розуміння В. Дільтаєм проблем автобіографіï та розуміння життя інших людей, без якого автобіографія немислима, подається в двох перших розділах першої частини роботи «Замітки до критики історичного розуму» [10]. Самоосмислення гарантує нам те, що давно минулі картини пережитого знову зринають в нашій пам'яті. Оглядаючись на пройдене, людина прагне досягнути саморозуміння. А воно, як відомо, здійснюється з певної точки зору, зумовленої категоріями мислення, цінності, мети та значення. Характеризуючи вищеназвані категорії, В. Дільтай відзначає категорію значення, як специфічну категорію історичного мислення. Зрозуміти себе людина може через самовираження, яке здійснюється у іï діях та письмі. Самовираження не лише презентує людські переживання, воно здатне сягнути всієї глибини життєвих зв’язків. Автобіографія є найвищим рівнем усвідомлення людиною свого життя: «Здесь Я постигает свой жизненный путь так, что осознается человеческий субстрат, исторические отночения, в которое оно вплетено. Таким образом, автобиография способна, наконец, развернуться в историческую картину; и ее гранищь и ее значение определень тем, что она извлечена из переживания, глубина которого делает понятным мое Я и мое отношение к миру. Размышление человека о самом себе остается цуелью и основой» $[10$, с. 141$]$.

В. Дільтай при досліджуванні проблеми ,згадування” робить основний акцент на найзначніших подіях, пережитих людиною. Правильність чи 
неправильність оцінки певного моменту найкраще показує саме життя. Однозначно, що будь-яка подія, яка зайняла місце в пам’яті, повинна мати для цього своє пояснення. 3 потоку людських переживань зберігаються лише ті, які мають особливе значення самі по собі та для зв'язності життя. А зв’язність життя, на думку філософа, створена самим життям [10, с. 139].

Підсумовуючи вкажемо на дві основні риси німецьких досліджень проблем художньої автобіографії. По-перше, в більшості випадків дослідження стосуються автобіографій чоловіків. По-друге, в аспекті вивчення окремих автобіографій виявляються телеологічні тенденції, які свідчать, що зображена в автобіографії історія життя, досягає своєї кульмінації й одночасно завершення. Питання правдивості автобіографічних розповідей, залежність автобіографій від сучасних їй філософських і суспільних теорій, художній вимисел, мотивація написання художньої автобіографії проходять червоною ниткою через проаналізовані нами дослідження німецьких літературознавців кінця ХХ-го століття.

\section{Література}

1. Misch Georg. Die Geschichte der Autobiographie / Georg Misch [Електронний ресурс]. - Режим доступу до видання : https://books.google.com. ua/books?id=bCwUAwAAQBAJ\&printsec=frontcover\&hl=uk\&source=gbs_ge_sum mary_r\&cad $=0 \# \mathrm{v}=$ onepage $\& \mathrm{q} \& \mathrm{f}=$ false.

2. Aichinger Ingrid. Probleme der Autobiographie als Sprachkunstwerk / Aichinger Ingrid // Die Autobiographie. Zu Form und Geschichte einer literarischen Gattung. - Darmstadt : Wissenschaftliche Buchgesellschaft, 1989. - S. 170-193.

3. Neumann Bernd. Identität und Rollenzwang. Zur Theorie der Autobiographie / Neumann Bernd // Germanistik. Bd. 13. Heft 2. Frankfurt / M, 1970. - S. 295-296.

4. Pfotenhauer Helmut. Literarische Antropologie. Selbstbiographien und ihre Geschichte - am Leitfaden des Lebens. Germanistische Abhandlungen / Pfotenhauer Helmut. - Stuttgart, Verlag : J. B. Metzler, 1987. - 336 s.

5. Ramm Elke. Warum existieren keine „klassischen” Autobiographien von 
Frauen? / Ramm Elke // Geschriebenes Leben. Autobiographik von Frauen. - Berlin, 1995. - S. 130-141.

6. Klein Christian. Einleitung : Biographik zwischen Theorie und Praxis. Versuch einer Bestandsaufnahme / Klein Christian // Grundlagen der Biographik. Theorie und Praxis des biographischen Schreibens. - Stuttgart Weimar, Verlag : J. B. Metzler, 2002. - 292 s.

7. Alt Peter-André. Mode oder Methode? Überlegungen zu einer Theorie der literaturwissenschaftlichen Biographik / Alt Peter-André // Grundlagen der Biographik. Theorie und Praxis des biographischen Schreibens. - Stuttgart Weimar : - Verlag J. B. Metzler, 2002. - S. 23-40.

8. Kuczynski Jürgen. Probleme der Autobiographie / Kuczynski Jürgen. Berlin-Weimar : Aufbau-Verlag, 1983. - $130 \mathrm{~s}$.

9. Müller Klaus-Detlef. Autobiographie und Roman / Müller Klaus-Detlef // Studien zur literarischen Autobiographie der Goethezeit. - Tübingen, Verlag : Niemeyer Max, 1976. - 392 s.

10. Дильтей В. Заметки к критике исторического разума / В. Дильтей // Вопросы философии. - 1988. -№4. - С. 135-141. 


\title{
МЕНТАЛЬНІСТЬ ЛІТЕРАТУР СВІТУ
}

УДК: 82.0

\author{
Айзенбарт Любомира, \\ старший викладач кафедри романської \\ філології та компаративістики \\ Дрогобицький державний \\ імені Івана Франка
}

\section{ГАЛИЧИНА НА ЛІТЕРАТУРНІЙ КАРТІ РІЗНИХ НАЦІОНАЛЬНИХ ЛІТЕРАТУР (КIH. XVIII - ПОЧ. ХX ст.)}

Описано історичні аспекти формування літературної карти Галичини у творчості письменників домінуючих національностей, які проживали на иій території (україниі, поляки, австрійці, євреї). Встановлено, щзо важливим складником літературної презентації галииького пограниччя постає культурний ландшафт.

Ключові слова: Галичина, ідентичність, галицьке літературне пограниччя, карта, ландиафт, простір, топос.

\section{Aizenbart L. Galicia on literary map of different national literatures (late XVII - early XX century.)}

The historical aspects of forming the literary map of Galicia in the works of writers of dominant nationalities living on this territory including Ukrainians, Poles, Austrians and Jews have been characterised. It has been determined that cultural landscape is an important component of the literary presentation of the Galician borderlands. This concept is closely linked with the idea of a map by means of which the authors build their own geographic space in their works. Literary maps become a reflection of the cultural landscape and restructure a certain territory at the same time. Each writer draws his own map of Galicia which defines his cultural landscape, including his own geography, history, culture and language.

Key words: Galicia, identity, Galician literary borderlands, literary map, landscape, space, topos.

Постановка проблеми. Важливим складником літературної презентації Галичини постає культурний ландшафт. Сьогодні тривають численні дискусії стосовно визначення цього термінопоняття. Для О. Галети культурний ландшафт однозначно «не зводиться до фізичного виміру, а виникає внаслідок просторових та політичних чинників i виражається через висловлювання» [2, с. 310]. Інші дослідники виводять його генеалогію із досліджень пам’яті (М. Гальбвакс. «Соцільні рамки пам’яті» (1925)), ще інші з культурної ідентичності (Я. Ассман. «Письмо, пам’ять про минуле і політична ідентичність у високих культурах давнини» (1992)). На нашу ж думку, поняття 